\title{
Analysis of Damaged Delimber Knives and the Possibility of Increasing their Ser- vice Life
}

Miroslava Ťavodová (0000-0002-7376-4189)ㄹ, Monika Vargová (0000-0003-0473-9032)1, Jozef Krilek (0000-00028349-5269) ${ }^{1}$, Dana Stančeková (0000-0003-0713-8750)²

${ }^{1}$ Faculty of Technology, Technical University in Zvolen, Študentská 26, 960 53. Slovak Republic, tavodova@tuzvo.sk,

${ }^{2}$ Faculty of Mechanical Engineering, University of Zilina, Univerzitná 1, 010 26, Zilina. Slovak Republic, Dana.Stancekova@fstroj.uniza.sk.

The article deals with the wear of the blades of the delimber device of harvester head. An input analysis of the materials of the fixed knife and movable arm parts was performed. It consisted of chemical analysis, evaluation of microstructure, hardness measurement by HRC methods and standard GOST 23.20879 Ensuring of wear resistance of products - wear resistance testing of materials by friction against loosely fixed abrasive particles. The original welded joint was analyzed, which ensured the connection of the blade and the fixed, resp. movable arm mechanism. Based on the findings, two blade replacement solutions have been proposed. The first was the application of hard metal by an OK 84.58 electrode and second use HARDOX 450 by welding with a fixed part or a mechanical gripping with screws. This was recommended based on previous research at the Faculty of Technology. The hardnesses of the original blade material were compared with the proposed solutions. The correctness of the proposed methods will be verified in the future and in operation.

Keywords: delimber knives, HARDOX 450, microstructure, hard facing, forestry

\section{Introduction}

In forestry, small and medium-sized harvesters are often used together with tractors with a load capacity of up to 3.6 or 9 tons [1]. This is due to their high performance in achieving good efficiency. By changing the harvesting methods, the process of gradual and especially from the tree method to the assortment method was gradually changed [2]. Harvester is a working machine, which consists of the following parts: engine, chassis, operator's control cabin, hydraulic crane, working equipment - harvester head. An important element of the harvester is its delimbing mechanism, which serves to delimbing off the tree trunk. In harvesting and transport machines, it is most often a knife. The knives are hyperbolic shaped and are mounted in a harvester head or on a telescopic boom, where one fixed and two movable knives are mounted (Fig.1a). The delimber trunk is stretched between these knives and the tree branches are cut off (Fig. 1b).

\section{Fixed knife}

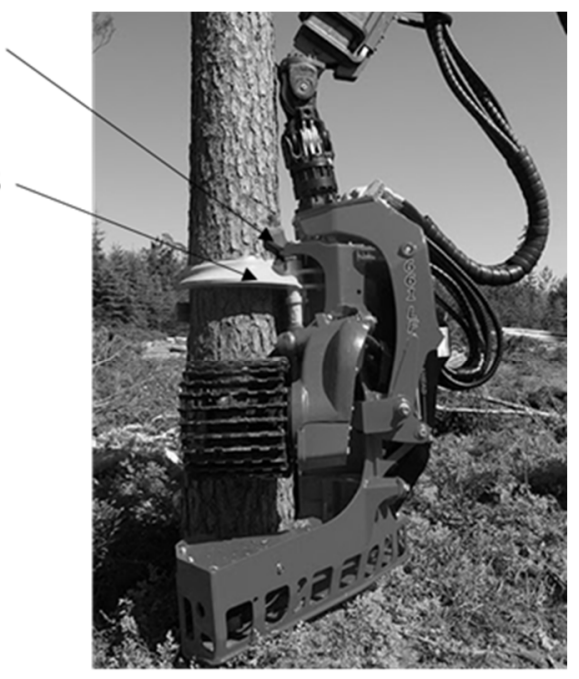

b.

Fig. 1 Harvester head-positioning of knives on the harvester head (a.); harvester head on a tree trunk (b.) [4] 
Delimbing knives should be able to best copy the shape of the trunk and have a long service life. Tool life time is important mainly from an economic point of view, so it is necessary to deal with the possibility of choosing a suitable material for the production of delimbing knives. It is necessary to focus mainly on exposed parts of the device, which are subject to strong abrasive wear as well as impact loads. Neglected maintenance and inregular inspection of exposed parts of the harvesting mechanism increase costs and previous quality of wood production $[3,4,5,6]$. In Fig. 2 shows the delimbing knives before and after the use of wood processing. Improvement in the maintenance of delimbing knives can reduce the RR of IRW by $5 \%$. Timely restoration of worn-out rollers can increase productivity by $2 \%$ and reduce fuel consumption by $5 \%[3,5]$.
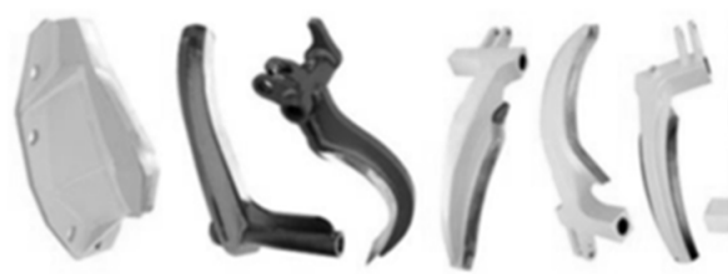
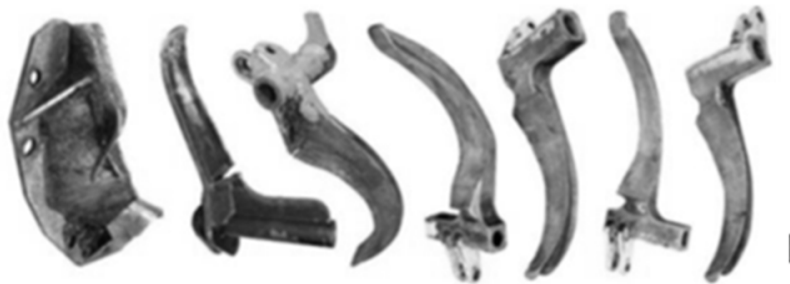

b.

Fig. 2 Examples of types of delimbing knives before (a.); after use in service (b.)

The knives of the harvester head are the most worn out. By analyzing and examining exposed parts of knives, we obtain information about the types and events of wear. So we can suggest ways to increase their service life. These may be a change in the material whose properties and structure will better withstand adverse working conditions. This includes the possibility of a design change to the movable knife of the harvester head $[7,8]$.

\section{Materials and methods}

As stated in [9] harvester delimbing knives are manufactured from special hardened and tempered Borarc alloy steel, ground and polished for best delimbing results. Special heat treated alloy steel guarantees strength and hardness (Fig. 3).

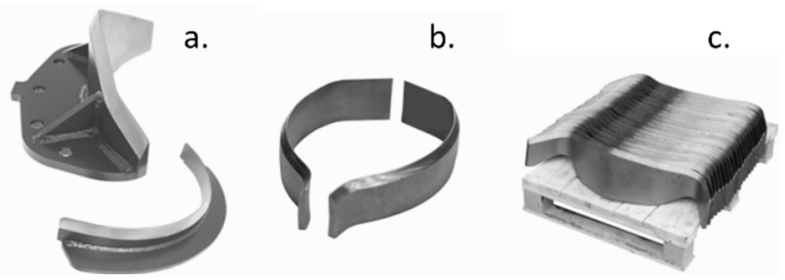

Fig. 3 Fixed and movable knife (a.); blades of fixed and movable harvester knife (b., c.) [9]

The new delimb blades are secured with a single bolt which operates a cam to lock the blades in place (NZ provisional patent application no. 742153). Replacing the blades requires no cutting, no welding, and can easily be done by one person with minimal tools. The single-bolt system avoids any of the issues associated with multi-bolt replaceable knife systems, and does away with unnecessary complexity (Fig. 4) [10].

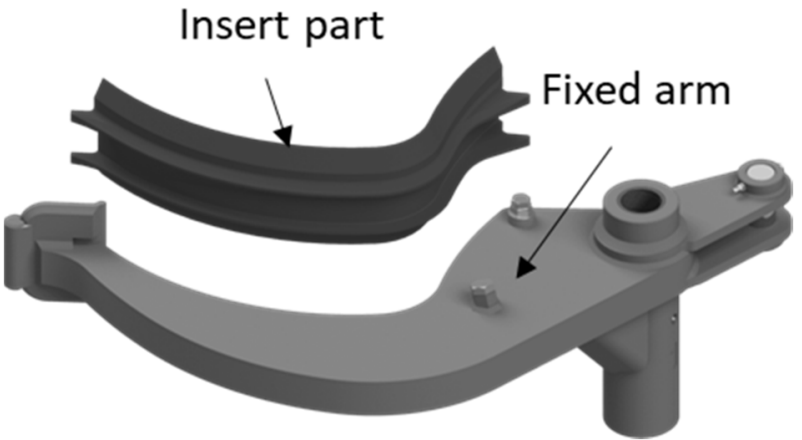

Fig. 4 Interchangeable insert for the fixed arm of the harvester head [10]

Similarly, the authors [11], based on the performed experiments, state that it is suitable for the crusher innovation to recommend the chain replacement with a shaped weldment made of HARDOX 400 material, the weldability of which is very good, and to make at least one hardfacing layer on its functional surfaces. With this innovation, the service life of the crushing segment could be extended by, more than ten-fold.

The authors $[7,8,12]$ state that for the removable cutting edge, the material HS12-1-2 was chosen, which was highly alloyed, resistant to shock, pressure, abrasion, and eliminated cracking. Based on the cutting force and the design of the special cutting knife, a stress analysis and a finite element method (FEM) was performed. This study confirmed the correctness of the selected material to produce the delimbing knife, which was designed using a replaceable cutting edge.

The use of hardfacing materials, which are better in structure and mechanical properties than the original material, is very widespread in technical practice. By hard welding deposit, we protect parts exposed to 
wear of various types [13]. The aim is to obtain resistance to a certain type of wear or certain specific properties. Although surfacing is primarily used to renovate worn parts to a usable condition in order to extend their service life, it is often useful to use this technology in the production of new parts. The actual component can thus be made of a cheaper material and better surface properties are achieved by welding the hard weld metal. Its properties are suitable for use in given conditions. However, increased hardness does not always mean better wear resistance or longer service life $[14,15]$. When choosing a weld metal, trade-offs often have to be made between the requirements of the different types of wear. Evaluation of the worn part may show that the primary wear factor is abrasion, but secondary shock is also present. The weld metal chosen must therefore have a very good resistance to abrasive wear, but also a good level of impact resistance $[16,17]$.

\section{Experiment}

The analysis was performed on samples taken from damaged parts of the harvester head. The arms - the moving part of the device and the fixed knife were analyzed. Both the movable arms and the fixed knife have blades attached to the base material using arc welding technology. These are a direct working tool in the delimbing of tribes.

In Fig 5 the extent of the damage can be seen. Detail Fig 5 a. shows damage to the fixed knife. Fig 5. b I. and b II show damage to movable arms. As can be seen from the figures, during operation, part of the blade was removed at the weld joint on both the arm part and the fixed knife. Fig. 6 shows sampling from the fixed knife and the arm of the harvester head.

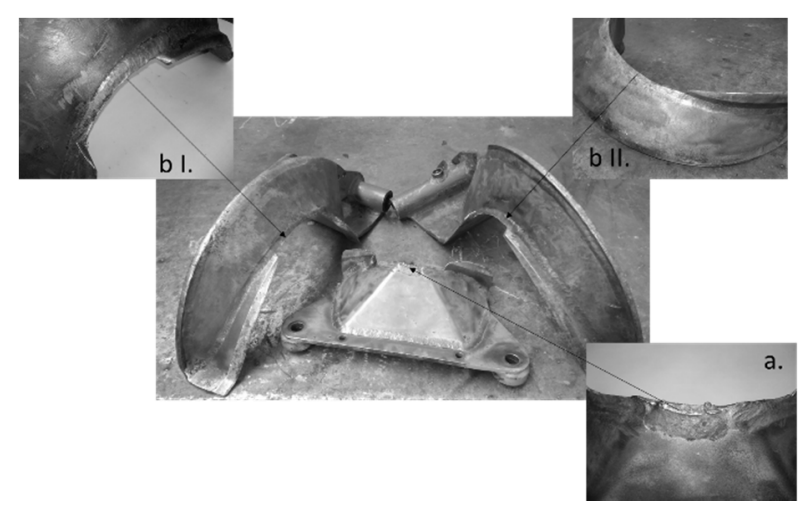

Fig. 5 Damaged parts of the blade - fixed knife (a.); arms of barvester (b I., b II.)
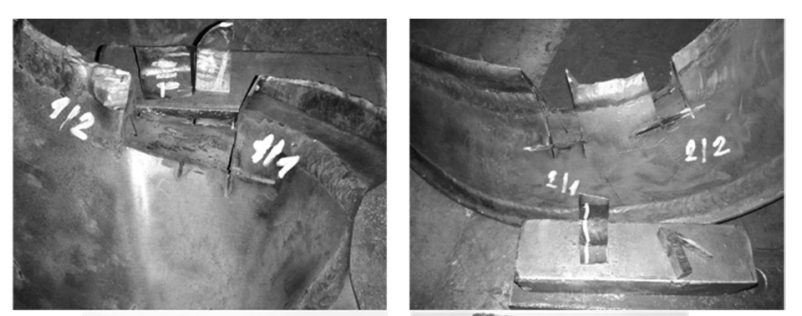

a.
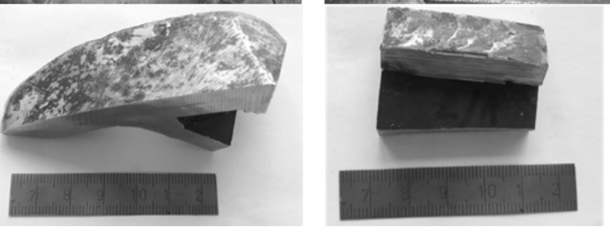

b.

Fig. 6 The samples from fixed knife (a.) and arm (b.)

\section{Results and discussion}

Chemical analysis of samples of investigated materials was performed by atomic emission method by spark discharge on Q4 TASMAN spectrometer. The results of the chemical analysis of the material of the blades - exposed parts of the delimbing mechanism of the harvester, are given in the Table 1.

Tab. 1 Chemical element analysis of blades

\begin{tabular}{|c|c|c|c|c|c|c|c|c|}
\hline Element & $\mathrm{C}$ & $\mathrm{Si}$ & $\mathrm{Mn}$ & $\mathrm{P}$ & $\mathrm{S}$ & $\mathrm{Cr}$ & $\mathrm{Ti}$ & $\mathrm{Fe}$ \\
\hline wt. $\%$ & 0.062 & 0.262 & 1.751 & 0.013 & $<0.150$ & 0.013 & 0.115 & rest \\
\hline
\end{tabular}

Based on the performed analysis, we can state that it is probably S420MC steel. It is a thermomechanically rolled steel with a higher yield strength, suitable for cold forming without cracking, with good abrasion resistance and weldability.

Chemical analyzes of the basic material of the arms and the fixed knife are in Table 2.

Tab. 2 Chemical elemental analysis of the basic material of the arms and the fixed knife

\begin{tabular}{|c|c|c|c|c|c|c|c|}
\hline Element & $\mathrm{C}$ & $\mathrm{Si}$ & $\mathrm{Mn}$ & $\mathrm{P}$ & $\mathrm{S}$ & $\mathrm{Cr}$ & $\mathrm{Fe}$ \\
\hline wt. $\%$ & 0.140 & 0.254 & 1.327 & 0.010 & $<0,150$ & 0.410 & rest \\
\hline
\end{tabular}

Based on the performed analysis, we can say in terms of structural, low-carbon steel with good weldability.

Additional input material analyzes were performed using light microscopy. Their goal was to identify the material, its microstructure and the main degradation mechanisms of damage to the delimbers - the blade of a fixed knife and the blade of a movable arm. In Fig. 7 is the microstructure of the basic material of the arm, the welded joint and the detail of the welded joint with HAZ. The material of the delimber arms was made of low carbon ferritic-pearlitic steel with an uneven ferritic grain size in the state without heat treatment. 

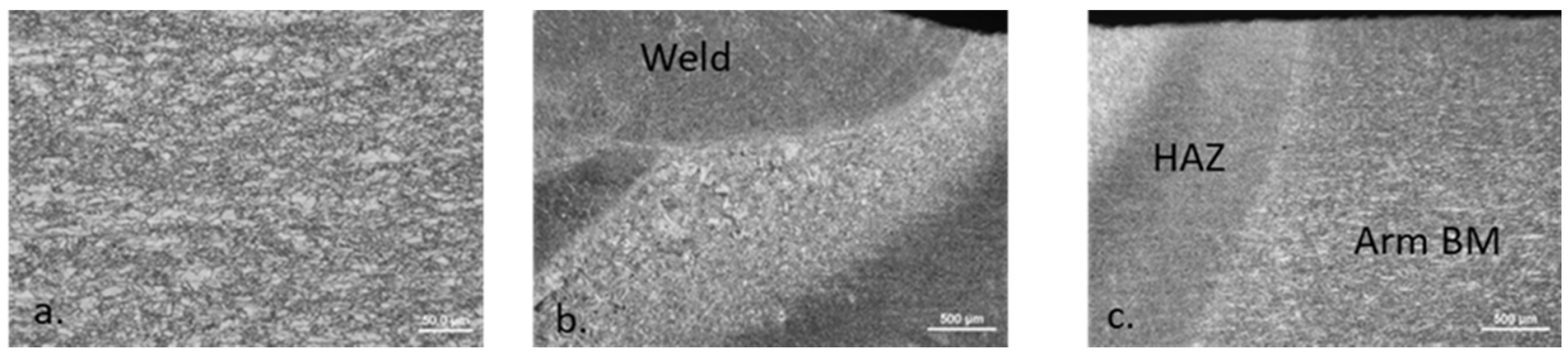

Fig. 7 Microstructure of material - a. basic material (BM) of arm; b. weld joint and BM; c. detail HAZ of BM weld joint

In Fig. 8 and 9 is the microstructure of the welded joint of the blade. No crack-type defects were observed by light microscopy in the blade-base material weld area.
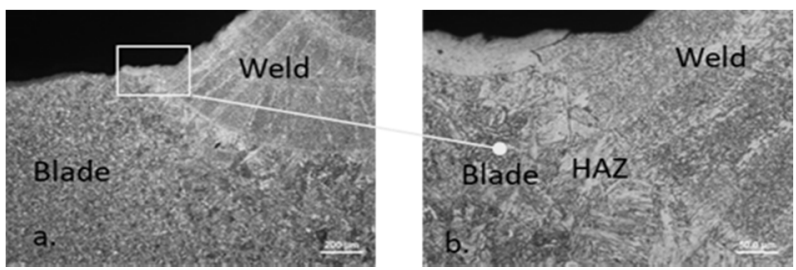

Fig. 8 Weld joint - blade (a.); detail of weld joint (b.)
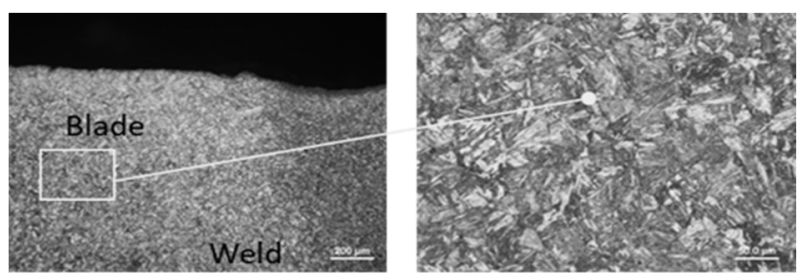

Fig. 9 Microstructure of blade material

In Fig. 10 shows the wear of the blades of the fixed knife (a.) and the movable arm (b.). We can state that they were abrasively worn with a small plastically deformed zone under the tool surface. The blades of the fixed and movable knife were in the refined condition. We can state that the structure corresponds to the technology of thermomechanically processed steel. The knives were worn abrasively, so that the thickness of the knife was gradually thinned, the profile of the knife lost stability, it was plastically deformed with the final phase of breaking the integrity. By cyclic repetition of the plastic deformation of the tool under the conditions of abrasion and also by the impact load, the material has been loss over time.
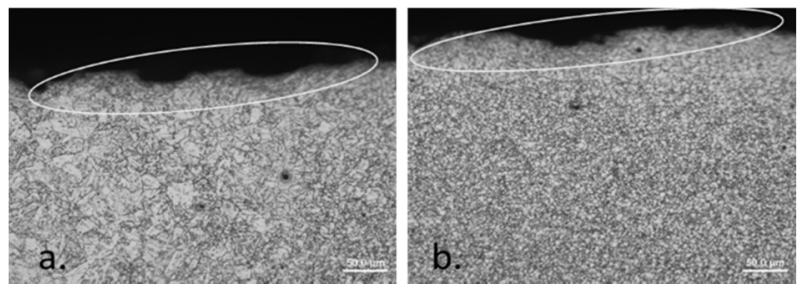

Fig. 10 Wearing blade of fixed knife (a.); wearing blade of movable arm (b.)
According to the ISO 6508-1: 2015 standard [19], the hardness of the blade of a fixed and a movable knife was measured by the Rockwell method. The average hardness value was 34 HRC.

Testing of wear resistance of materials to free abrasive particles was performed according to standard GOST 23.208-79 Ensuring of wear resistance of products - wear resistance testing of materials by friction against loosely fixed abrasive particles [20]. Three samples, prepared by abrasive water jet machining (AWJM), were prepared for testing according to the standard. Subsequently, they were machined by milling and ground on a magnetic grinder to achieve precise dimensions and surface roughness. OTTAWA $\mathrm{SiO}_{2}$ silica sand with a grain size of $0.1-0.3 \mathrm{~mm}$ was used as abrasive. The hardness corresponds to the seventh hardness grade of the Mohs scale, which corresponds to the Rockwell hardness value of 54 HRC [15]. The blade material S420MC was used as a standard sample - etalon. The hardness coefficient $\mathrm{K}_{\mathrm{Ti}}$ for the blade material was calculated from the hardness ratio of the etalon and the abrasive, according to Formula $1.1[16]$ :

$$
K_{T}=\frac{H}{H_{a}}[-]
$$

Where:

H...Hardness of the sample material [HRC],

$\mathrm{H}_{2} \ldots$... Hardness of abrasive material $\left(\mathrm{SiO}_{2}\right.$ silica sand) [HRC].

To determine the average weight loss, the sample was weighed 3 times after each cycle and its average weight was recorded in the table. The length of the friction path in one cycle was $153.6 \mathrm{~m}$. Subsequently, the average weight loss of $\mathrm{W}_{\mathrm{hi}}$ was calculated. It is used to calculate the relative abrasion resistance $\Psi_{a b r}$, which is calculated according to formula 1.2:

$$
\boldsymbol{\Psi}_{a b r}=\frac{W_{h E}}{W_{h V}}[-]
$$

Where:

$\mathrm{W}_{\mathrm{hE}} \ldots$ Weight loss of etalon [g],

$\mathrm{W}_{\mathrm{hV}} \ldots$ Weight loss of compared sample $[\mathrm{g}]$.

Since the S420MC sample was determined as an etalon, the relative abrasion resistance does not calculate. The values found from the test are given in Tab. 3. 
Tab. 3 Results from abrasion resistance test for material S420MC

\begin{tabular}{|c|c|c|c|}
\hline & $\begin{array}{c}\text { Hardness coefficient } \\
\mathrm{K}_{\mathrm{Ti}}[-]\end{array}$ & $\begin{array}{c}\text { Average weight loss } \\
\mathrm{W}_{\text {hi }}[-]\end{array}$ & $\begin{array}{c}\text { Relative abrasion } \\
\text { resistance } \psi_{\mathrm{abr}}[-]\end{array}$ \\
\hline S420MC & 0.63 & 0.1049 & - \\
\hline
\end{tabular}

The results of the input analyzes performed on the damaged parts of the branching knives identified the material of the knife blades as well as the basic material of the knives (Tables 1 and 2). Microscopic analysis revealed the structure (Fig. 7-9) as well as the mechanism of plastic deformation, which causes wear and loss of material (Fig. 10). Based on these facts as well as the theoretical facts described in the previous chapter, two blade replacement options have been proposed:

Based on the findings, two possibilities blade replacement options have been proposed:

- To apply a hardfacing by electrode OK 84.58 to the base material of the fixed knife and the movable arms.

- To replace the blade material with HARDOX 450 steel - by welding or by inserting of new blade.
The following tests and methods were used for evaluation:

- HRC hardness measurement.

- Microscopic analysis of the material structure.

- Determination of the value of abrasive wear of the material.

\subsection{Application the hardfacing electrode 84.58}

Electrode OK 84.58 EN 14700: E Z Fe 6 is a highyield electrode for hard facing functional surfaces that resist wear under simultaneous impact stress with the required partial corrosion resistance, e.g. parts of agricultural and forestry machinery, mixers, transport equipment, etc. Machining is possible by grinding. The hardness of the weld metal without preheating reaches the value of 52-59HRC [21]. Chemical composition of the OK electrode 84.58 is in Table 4.

Tab. 4 Chemical composition of the OK electrode 84.58

\begin{tabular}{|c|c|c|c|c|c|}
\hline Element & $\mathrm{C}$ & $\mathrm{Si}$ & $\mathrm{Mn}$ & $\mathrm{Cr}$ & $\mathrm{Fe}$ \\
\hline wt. $\%$ & 0.7 & 0.6 & 0.7 & 10.0 & rest \\
\hline
\end{tabular}

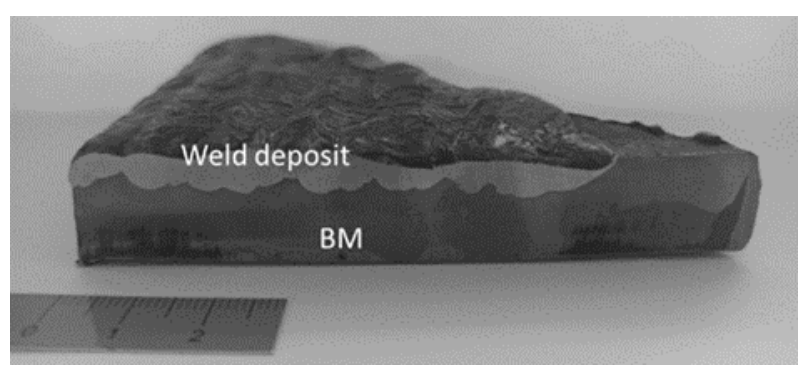

Fig. 11 Macroscopic image of welded metal OK 84.58

An electrode with a diameter of $3.2 \mathrm{~mm}$ was used. The electrode was dried in a ZEPACOMP oven
(KEMPPI MINARC 150) for 2 hours at $200^{\circ} \mathrm{C}$, without preheating the sample. The set welding voltage was $\mathrm{U}=21.5 \mathrm{~V}$ and welding current $\mathrm{I}=140 \mathrm{~A}$, welding time $\mathrm{t}=316 \mathrm{~s}$, welding position PA. The hard metal was applied in one layer on a sample of the material of the delimbing knife (Fig.11).

Hard weld deposit of OK 84.58 was evaluated by light microscopy. We observe polyhedral and acicular microstructure (Fig. 12a.) and the presence of larger carbides (Fig. 12b.) We can state that there was sufficient mixing of the material, without visible cracks and defects in the melting zone. On the analysis of the hard weld deposit interface on the BM (Fig. 12c) we see the simultaneous diffusion mixing.
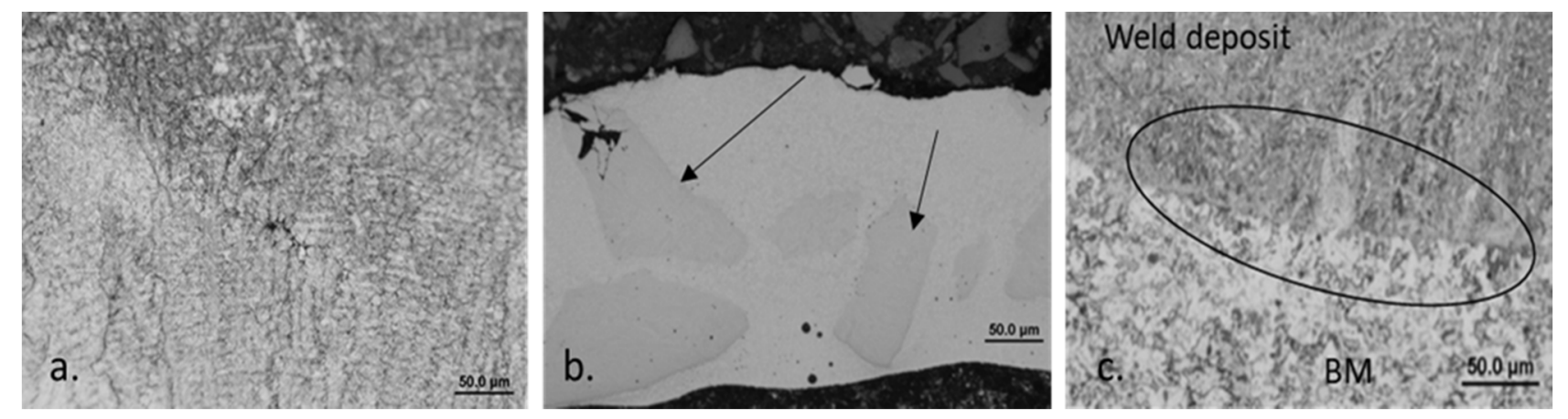

Fig. 12 Hard weld deposit OK 84.58 (a., b.); mixing of electrode OK 84.58 with the base material (c) 
To verify the hardness value of the hard facing metal, the hardness was measured at six locations by the Rockwell method. The average value reached 50HRC.

Testing of wear resistence, sample preparation and test procedure were performed as for material
S420MC. The hardness coefficient $\mathrm{K}_{\mathrm{Ti}}$ was calculated according to formula 1.1 and the relative abrasion re-

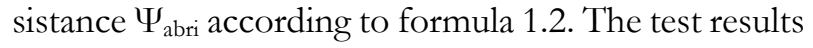
are shown in Tab. 5.

Tab. 5 Results from abrasion resistance test of $O K 84.58$

\begin{tabular}{|c|c|c|c|}
\hline & $\begin{array}{c}\text { Hardness coefficient } \\
\mathrm{K}_{\mathrm{Ti}}[-]\end{array}$ & $\begin{array}{c}\text { Average weight loss } \\
\mathrm{W}_{\text {hi }}[-]\end{array}$ & $\begin{array}{c}\text { Relative abrasion } \\
\text { resistance } \psi_{\text {abr }}[-]\end{array}$ \\
\hline OK 84.58 & 0.93 & 0.0066 & 15.89 \\
\hline
\end{tabular}

\subsection{Replacement steel blades HARDOX 450}

As the properties of this steel allow its use also for load-bearing parts of structures and application in abrasive and aggressive environments, it was proposed to use HARDOX 450 material as a blade. As stated by the material manufacturer HARDOX has better wear resistance, higher load capacity, longer service life compared to ordinary steel with the same hardness and good weldability. The hardness of this steel is 450 HBW [22]. It is available in the form of sheet metal in thicknesses from $0.7 \mathrm{~mm}$ up to $160 \mathrm{~mm}$. The yield strength for sheets up to $80 \mathrm{~mm}$ thick is $\mathrm{Re}=1100$ $\mathrm{MPa}$. The materials of plates are delivery in states Quenched or Quenched and Tempered [22, 23].
When choosing an electrode for welding the base material with an abrasion-resistant sheet, we used the data for welding HARDOX. Electrode OK 48.00 EN ISO 2560 - A: E 424 B 42 H 5. it is the most extended $\mathrm{OK}$ base electrode for welding illegal and low-alloy steels, especially tested P235/S235 (non-alloy structural steel of common quality, class 11 according STN) to P420/S420 (fine-grained structural steel) and others. It can be used for all welding positions except the vertical top-down position. The coat of the electrode with reduced moisture content gives tough weld metal, resistant to cracking and low hydrogen content [21]. Chemical composition of the electrode OK 48.00 is in Table 6.

Tab. 6 Chemical composition of the electrode OK 48.00

\begin{tabular}{|c|c|c|c|c|}
\hline Element & $\mathrm{C}$ & $\mathrm{Si}$ & $\mathrm{Mn}$ & $\mathrm{Fe}$ \\
\hline wt. $\%$ & 0.06 & 0.5 & 1.2 & rest \\
\hline
\end{tabular}

The electrodes had to be dried before welding. Drying took place in a ZEPACOMP oven (KEMPPI MINARC 150) for 2 hours at $350^{\circ} \mathrm{C}$. The preheating of both welded parts with a thickness of $10 \mathrm{~mm}$ took place at a temperature of $150^{\circ} \mathrm{C}$. The welded joint consists of three layers - root, filler and cover. The root and fill electrodes had a diameter of $2.5 \mathrm{~mm}$ and a cover of $3.2 \mathrm{~mm}$. The set welding voltage was for the root layer $\mathrm{U}=24 \mathrm{~V}$ and welding current $\mathrm{I}=80 \mathrm{~A}$, for the filling layer the voltage $\mathrm{U}=23 \mathrm{~V}$ and welding current $\mathrm{I}=95 \mathrm{~A}$ and the cover layer the welding voltage was $\mathrm{U}=21.5 \mathrm{~V}$ and the welding current $\mathrm{I}=14$ A.

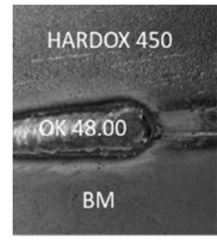

a.

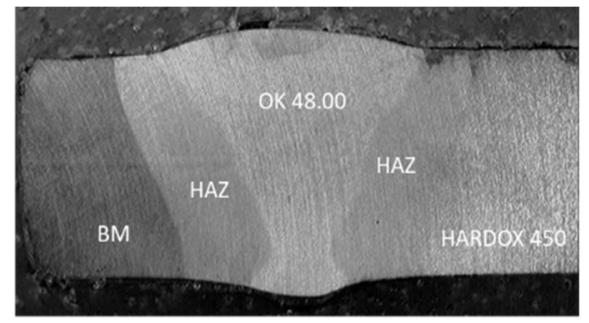

b.
Fig. 13 Welded joint (a.); macroscopic image of welded joint (b.)

Fig. 13 shows a welded joint of HARDOX 450 material and base material with OK 48.00 electrode and a macroscopic image of the welded joint (Fig. 13b). The macroscopic image proves that the welded joint is free of defects. No cracks, cavities or other defects are observed that would reduce the quality of the joint.

The figure shows the microstructures of the base material (Fig.14a), the weld metal of the OK 48.00 electrode (Fig. 14 b) and the HARDOX 450 steel (Fig. 14c).

Compared to the microstructure of the weld from the input analysis, the structure of the weld metal OK 48.00 is different. The structure in Fig. $14 \mathrm{~b}$ is finergrained than the structure on the original weld (Figs. $7 \mathrm{~b}$ and $8 \mathrm{~b})$. We assume that a different electrode was used on the original weldment. When choosing the OK 48.00 electrode, we used the data for HARDOX welding [13]. In Fig. 14c is the structure of HARDOX. We can state that this is a structure obtained by hardening and tempering, thus achieving a sorbitic structure.
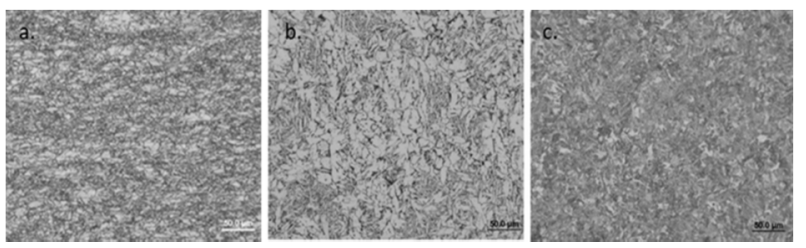

Fig. 14 Microstructures of welded joint materials for movable arm BM (a.), electrode OK 48.00 (b.), HARDOX 450 (c.) 
Microscopic analysis of the blades revealed that the steel had been thermomechanically processed (Fig. 9). This method of material treatment is economically demanding. The structure of the HARDOX 450 material should ensure sufficient abrasion resistance at comparable or even lower material prices.

According to ASTM E 140-97:1999 [24], value $450 \mathrm{HBW}$ corresponds to approximately to 47HRC.
To verify the hardness value of the welded metal, the hardness was measured at six locations by the Rockwell method. The average value was 45HRC.

Testing of wear resistence, sample preparation and test procedure were performed as for material S420MC and OK 84.58. The test results are shown in Tab. 7 .

Tab. 7 Results from abrasion resistance test of $H A R D O X 450$

\begin{tabular}{|c|c|c|c|}
\hline & $\begin{array}{c}\text { Hardness coefficient } \\
\mathrm{K}_{\mathrm{Ti}}[-]\end{array}$ & $\begin{array}{c}\text { Average weight loss } \\
\mathrm{W}_{\mathrm{hi}}[-]\end{array}$ & $\begin{array}{c}\text { Relative abrasion } \\
\text { resistance } \psi_{\text {abr }}[-]\end{array}$ \\
\hline HARDOX 450 & 0.83 & 0.0082 & 12.79 \\
\hline
\end{tabular}

Were created 4 graphs to compare the results. In Fig. 15 (Graph 1) we see a graph with hardnesses of material S420MC, hardface OK 84.58 and material HARDOX 450. The material of the blade of the tool S420MC has a very low hardness of 34HRC. By modifying it by hard-facing or replacing it with abrasionresistant HARDOX 450, we wanted to achieve a higher hardness of the tool blade so that it could better withstand adverse working conditions. The highest hardness was achieved by OK 84.58, namely 50 HRC. In Fig. 15 (Graph 2) we see a comparison of the hardness coefficients of the tool blade material, the OK 84.58 weld metal and the HARDOX 450 material. The highest hardness coefficient was reached by the OK 84.58 .

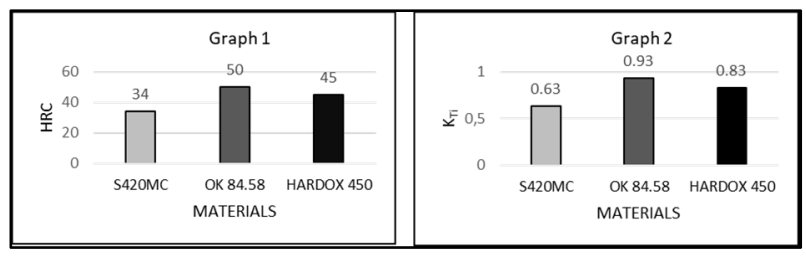

Fig. 15 Comparison of HRC hardness and koeficients of hardness $K_{T i}$

In Fig. 16 (Graph 3) we see a graph with weight losses of S420MC, OK 84.58 and HARDOX 450 for better comparison. As we can see, the tool blade material (S420MC) had the highest weight loss. This also caused its rapid wear. By welding on the blade, resp. by replacing it with HARDOX 450, we reduced the size of the average weight loss. The lowest weight loss was achieved by OK 84.58. From Graph 3 we can state that the weldment $\mathrm{OK} 84.58$ can best withstand abrasive wear among the tested treatment methods. This statement is also proved by the calculations of relative resistance to abrasive wear. Hardfacing by $\mathrm{OK}$ 84.58 achieved almost 16-times higher resistance to abrasive wear compared to S420MC, and Hardox 450 almost 13-times higher. The S420MC material has a value of 1 in Graph 4 because it was used as a reference sample. A comparison of the values of the relative abrasion wear resistance can be seen in Fig. 16 (Graph 4).

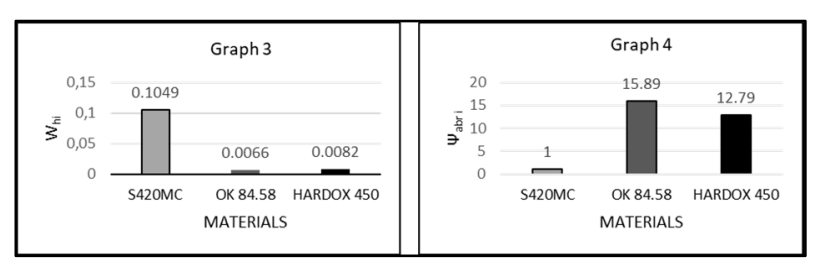

Fig. 16 Comparison of $W_{b i}$ weight loss and values of relative abrasion resistance $\psi_{a b r}$

A large part of the knife (Fig. 5) was worn due to repeated cyclic stress. The material was strengthened, which over time could not resisted abrasion due to its structure. Such a phenomenon has also been described by the authors [16,25,26]. Significant plastic deformation caused visible wear of the knife blade (Fig. 10). As can be seen from Fig. 5, the original blade has been completely removed at one place. It was as if the rest of the worn blade had been "cut off and avoided" at the joint at the weld. Theoretically, the same case could occur when will to weld a blade from HARDOX 450. Figure 17 shows a design for replacing the blade of the movable arm, according the study of authors [7].

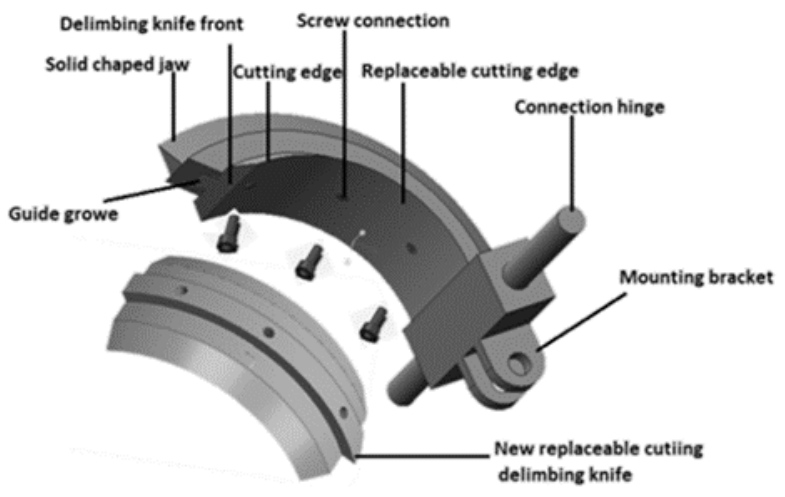

Fig. 17 Delimbing knife with replaceable cutting edge [7]

It is a mechanical fastening with three screws. The use of HARDOX 450 steel therefore represents one of the possible applications even in such a mechanical way of connection with the base material of the movable arm. 
Based on the results, we can state that the methods of modification of exposed parts of the movable arm and the fixed knife of the harvester head would increase the service life. The proposed options need to be verified in operation. Operational experiments are planned in the near future.

\section{Conclusion}

Working in forestry is demanding for both people and techniqe. The presence of a large number of factors that affect the processing of wood in individual forestry work requires complex analyzes. Great attention must be paid to the material of technical equipment.

The article presents two ways to increase the service life of the delimber knives blade. The first option is the application of hardfacing by an OK 84.58 electrode to the base material S420MC. Based on the laboratory results of the abrasive wear test, we can state that the abrasion resistance of the hardfacing material of the OK 84.58 electrode is 16-times higher than the original material. This presupposes a higher resistance of the material to abrasive wear during delimbing. The hardness of the HRC is one third higher, which is confirmed by the calculated value of the hardness coefficient $\mathrm{K}_{\mathrm{Ti}}$ The second option considered in the experiment is to use HARDOX 450. It has an abrasion resistance 13-times higher than the originally used material. It also has a higher hardness, which was determined by the HRC method and the calculation of the hardness ratio coefficient. The article also presented the proposed application of HARDOX 450 material in two ways. It can be welded with the base material designed by the electrode OK 48.00. According to the microscopic analysis, the welded joint is of sufficient quality, without the presence of defects and defects. The second way is to fasten the knife blade mechanically, using screws. This method is a part of the design, which was processed within the research of new design proposals of branching knives of harvester heads, carried out at the Faculty of Technology.

Finding new ways to increase the life of individual components and tools is time consuming. But the results of experiments that will be tested in practice and help increase management efficiency will bring economic and environmental benefits for forestry companies in the future.

\section{Acknowledgment}

This article was created during the processing of the project VEGA 1/0609/20" Research of the cutting tools at the dendromass processing in agricultural and forestry production." and IPA 1/2021 „Proposal of possibilities to increase the service life of tools working in forestry. "

\section{References}

[1] KUCHTA, T. (2002) Přínos malých vyvážecích souprav v sortimentní metodě. In. Lesnická práce 10/2002, Kostelec nad Č. Lesy, s. 459.

[2] DVOŘÁK, J., et al. (2011) The Use of Harvester Technology in Production Forests. Kostelec nad Černými Lesy: Lesnická práce, s.r.o., 156 s.

[3] GERASIMOV, Y., SELIVERSTOV, A., SYUNEV, V. (2012) Industrial Round-Wood Damage and Operational Efficiency Losses Associated with the Maintenance of a Single-Grip Harvester Head Model: A Case Study in Russia, September 2012, In: Forests 3(4):864-880, DOI: $10.3390 / \mathrm{f} 3040864$

[4] KOVÁČ J. et al. (2011) Analysis of the frictional coefficient at the pulling load on the tilted, In. Acta facultatis technicae, Vol. 16, pp. 65-72, 2011.

[5] RUKOMOJNIKOV, K. P., VEDERNIKOV, S.V., KUPTCOVA, V.O. (2019) Modernization of Harvesting and Processing Head. Southeast Eur for 10 (2): 181-185. DOI: https:// doi.org/10.15177/seefor.19-10.

[6] CACOT, E. et al. (2016) New delimbing tool for harwood trees: feedback on new ribbed knives after one year experince. In. Formec 2016, From Theory to Practice: Challenges for Forest Engineering; 49th Symposium on Forest Mechanization, Warsaw, Poland 2016: 37-43.

[7] MELICHERČÍK, J., KRILEK, J., HARVÁNEK, P. (2020) Simulation of stress and strain analysis on a delimbing knife with replaceable cutting edge, In. BioResources, 15(2), 3799-3808.

[8] HATTON, B. et al. (2015). Experimental determination of delimbing forces and deformations in hardwood harvesting. In. Croatian Journal of Forest Engineering 36(1), 43-53.

[9] Harvesting head delimbing knives [on line]. 16.08.2021. Available from https://neilsonengineering.com.au/product/harvesting-headdelimbing-knives/

[10] Replaceable delimb knife inserts [on line]. 09.07.2021. Available from https://woodsmanpro.co.nz/woodsman_product/replaceable-delimb-knife-inserts /

[11] VIŇÁŠs, J., et al. (2021) Innovation of Biomass Crusher by Application of Hardfacing Layers. In. Metals 2021, 11, 1283. https://doi.org/10.3390/ 
[12] BODNÁR, F., et al. (2016) Influence of boundary conditions on the solution to a mathematical model for a given wooden plate, In. BioResources, Vol. 11, No 1. ISSN: 1930-2126.

[13] ŤAvODOVÁ, M., VARGOVÁ, M., FALAT, L. (2020) Possibilities of modification of ploughshares used for winter maintenance of forest roads. In Manufacturing technology, Vol. 20, No. 6, s. 834-844. ISSN 1213-2489.

[14] KOVÁČ, I. et al. (2014) Creation of wear resistant boride layers on selected steel grades in electric arc remelting process. In Kovové materiály. ISSN 0023-432X, 2014, vol. 52, no. 6, s. 387-394.

[15] FALAT, L., et al. (2019) Microstructure and abrasive wear resistance of various alloy hardfacings for application on heavy-duty chipper tools in forestry shredding and mulching operations. In Materials. 2019. s. 2019. ISSN 19961944.

[16] ŤAvODOVÁ, M., HNILICA, R. (2020) Assessment of selected properties of treated tool surfaces examined to increase tool life time. In Manufacturing Technology, Vol. 20, No. 2, s. 257264. ISSN 1213-2489.

[17] MONKOVÁ, K., et al. (2018) Tool Life Investigation of the Thread Making Tools, In.Manufacturing Technology, 18(5):787-792, ISSN 12132489.

[18] ISO 6506-1:2014 Metallic materials — Brinell hardness test — Part 1: Test method.
[19] ISO 6508-1:2015 Metallic materials — Rockwell hardness test — Part 1: Test method.

[20] GOST 23.208-79 Ensuring of wear resistance of products. Wear resistance testing of materials by friction against loosely fixed abrasive particles [online]. cit.20.01.2020. Available from https://www.internet-law.ru/gosts/gost/4066/

[21] ESAB - Opravy a údržba, Př́ručka svařování (2011) [on line]. 09.07.2021. Available from http://products.esab.com/ESABImages/prirucka $\% 206 \% 20$ vydani $\% 202011$.pdf

[22] Data Sheet HARDOX 450, SSAB, [on line]. 24.01.2022. Available from https://www.mtladv.com/wp-content/uploads/2016/01/168_HARDOX_450_UK_Data -Sheet.pdf

[23] HARDOX 450 [on line]. 09.07.2021. Available from /https://www.ssab.com/products/brands/hardox/products/hardox-450

[24] ASTM E 140 - 97:1999 Conversion for NonAustenitic Steels, Table 1.

[25] ŤAVODOVÁ, M., et al. (2018) Deformation of exposed parts tool for crushing of undesirable advance growths. In. Acta technologica agriculturae, Vol. 21, No. 4, pp 169-176. ISSN 1335-2555.

[26] STEINMETZ, D. et al. (2013) Revealing the strain-hardening behavior of twinning-induced plasticity steels: theory, simulations, experiments. In. Acta Mater. 61, 494-510. 